\title{
THE WORK OF THE GRADUATE OF RIGA POLYTECHNIC INSTITUTE AUGUSTS BAUMANIS (1883-1966) IN ENGINEERING SCIENCE AND PEDAGOGY
}

\author{
ALĪDA ZIGMUNDE* \\ Riga Technical University
}

\begin{abstract}
Summary. Engineer, entrepreneur and teacher Augusts Baumanis (1883-1966) is one of the graduates of Riga Polytechnic Institute (RPI) who were renown in the 1920s and 1930s. Latvia's growth without his activities is unthinkable. After graduating from the Department of Chemistry (1913) of RPI, he worked in Russia. In 1919, after returning to Latvia, A. Baumanis became involved in oil production and in export of wooden boards. From 1928 to 1931, he travelled around South Africa with his family and worked in gold mines. After returning to Latvia, he started to work as a teacher. The aim of the article is to reveal the life of engineer $A$. Baumanis, to introduce readers to the Latvian entrepreneur and to analyse the problems he had to face in business and pedagogy during the interwar period.
\end{abstract}

Key words: Augusts Baumanis, Riga Polytechnic Institute, engineers and teachers of Riga.

\section{Introduction}

The activities of engineers who graduated from the «old» RPI are connected not only with Tsarist Russia but also with Western Europe and America. Latvian engineers worked in many well-known companies all over the world as well as established their own enterprises. A. Baumanis turned to oil extraction and box manufacturing business soon after the establishment of the independent Republic of Latvia.

He was one of the few Latvians whose family in the beginning of the 20th century had the opportunity to provide education for both sons Jānis Baumanis (1878-1945) and Augusts Baumanis (1883-1966).

\footnotetext{
* Corresponding author.

E-mail: alida.zigmunde@rtu.lv
} 
The history of engineering science in Latvia was made by the performance of every engineer, so in 2018, marking the 135th anniversary of A. Baumanis, the author of the article did the first major research about him. The aim of the article is to identify and analyse the documents of the Latvian State Historical Archive and the materials of Latvian libraries to popularize A. Baumanis' life in the first half of the 20th century.

\section{The Baumanis' Family}

A. Baumanis was born on 21 April 1883 in Riga. His mother, Trine Baumane (born Vecvagare; 1850-1929), was born in Baldone parish [1] and moved to Liepāja city after marrying Jēkabs Baumanis (1850(?)1885). Their first son Jānis (1878-1945) was born in Liepāja city. Soon the family moved to Riga and besides brothers Jānis and Augusts two more children were born - daughter Anna (married Priedkalne; 18731949) and the youngest son Jēkabs (1885-?) [2]. Father, Jēkabs Baumanis, was a worker and mother - a housewife. Unfortunately, on 12 March 1885, head of the family passed away at the age of 35 [3] and the mother had to take care of the big family. Though Trine Baumane was illiterate, one of her goals was to give her children good education. In 1899, the eldest son Jānis, graduated from the Liepāja City Real School and began studies in the Department of Mechanics of RPI. He received the diploma of engineering technologist in 1904 [4]. A more extensive study of his progress can be found in another article of this journal by L. Gaitniece and A. Zigmunde - «Lifetime of Engineer, Entrepreneur and Teacher Jānis Baumanis (1878-1945)». After the eldest son had received education, the second son - A. Baumanis - began his studies in the Department of Architecture of RPI in 1904.

During Augusts' studies, his custodian was his sister Anna who lived in the centre of Riga, at Lielās Nevas (since 1923 - Blaumaña) iela, near the RPI building at 4 Kronvalda bulvāris, where the young man was studying. Sister Anna Baumane was a midwife and was married to a well-known doctor Andrejs Priedkalns (1873-1923). In the first half of the 20th century, the Priedkalns family was highly respected and well-known among the Rigans. Nowadays we remember this family for two reasons - A. Priedkalns was Director of Riga Children's Hospital and a doctor and family friend of poet Rainis [5]. After World War I, A. Baumanis' mother, Trine Baumane, lived in Jürmala city, then Riga, where her daughter with her family took care of her. During the last years of her life, she fell ill and passed away in 1929 [6].

A. Baumanis married Margareta Elfrīda Irma (usually called Irma) Pērkons (1890-?). In 1920, Irma gave birth to twins: Jānis Arnolds 
was born on 14 September and Alise Viktorija - on 15 September. On 2 January 1921, when the children were baptized, persons close to Augusts were chosen as godparents - the godfather of daughter Alise Viktorija was Andrejs Priedkalns, husband of his sister and his wife Anna Priedkalne became the godmother of Augusts' son Jänis Arnolds [7]. During the Nazi Germany occupation in the beginning of 1942, son Jānis Arnolds, was conscripted into labour service and went to Germany. He returned to Latvia in early 1943 [8]. He had to stop his engineering studies because he was drafted into the Latvian Legion. He was injured and felt consequences for the rest of his life. At the end of World War II, Jānis Arnolds Baumanis took refuge to Melbourne, Australia. Until his death in 2010, he was known in the scouts' community [9].

A. Baumanis' wife Irma was actively involved in the work of «Guards Organisation» and participated in breed dog shows with her dogs. She was wealthy - she owned real estate in Jürmala city and the family had properties in Riga. Irma's sister Alise Kaugare (1887-1971) was a teacher.

\section{A. Baumanis' Study Years}

In 1904, 40 young people, including A. Baumanis, graduated from the supplementary class of the Riga City Real School. Many of them started their studies at RPI: Alfred Roenne (1887-1925), Friedrich Nauck (18851948), Kurt Rathfelder (1883-?), Kärlis Rozittis (1886-?) and others [10]. A. Baumanis began his studies in the Department of Architecture [11], but after less than a month he changed his mind and continued his studies in the Department of Chemistry [12].

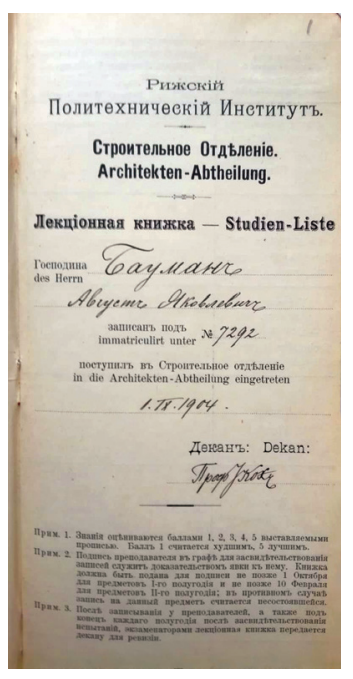

Figure 1.

Title page of a lecture book by A. Baumanis, student of the Department of Architecture of RPI (1904) [11].

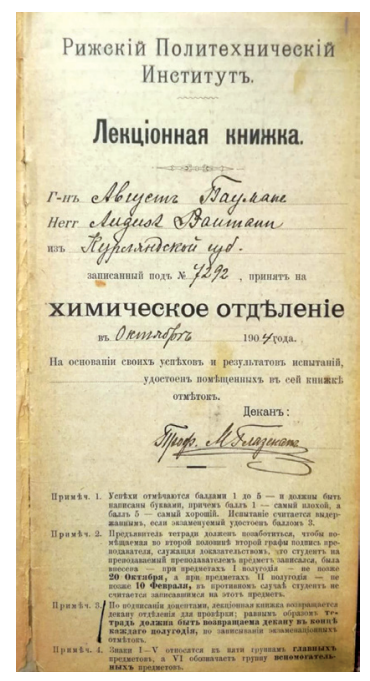

Figure 2. Title page of a lecture book by A. Baumanis, student of the Department of Chemistry of RPI (1904) [12]. 
His teachers were famous chemists of Riga: Professor Carl Blacher (1867-1939), Maximilian von Glasenapp (1845-1923), Paul Walden (1893-1957) and others. He interrupted studies in 1911/1912, seems that there was a problem with the payment of the study fee. He received the diploma of engineer-technologist in 1913.

Augusts' schoolmate, grandson of the first director of RPI Friedrich Nauck, also received the diploma of engineer-technologist in 1913. He graduated from the Department of Mechanics.

In September 1904, soon after enrolling at RPI, A. Baumanis joined the oldest student corporation «Selonia» founded in Riga and in the autumn of 1905, he became full member of corporation [13].

Figure 3. Augusts Baumanis (around 1932) [14].

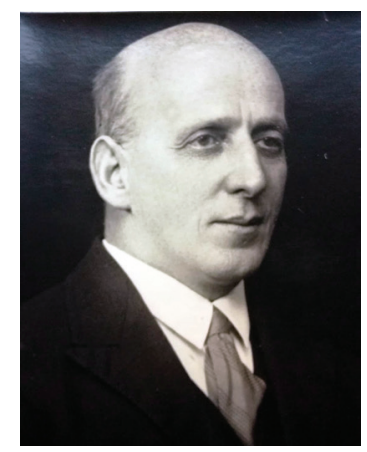

In September 1932, at the age of 49, Baumanis enrolled in the Department of Mathematics of Faculty of Mathematics and Natural Science of the University of Latvia, but in 1938, he interrupted his studies [14]. It was difficult to combine studies with work and he did not obtain the second higher education.

\section{The Work of Engineer and Entrepreneur}

There was no need to worry about finding a job having the diploma of RPI - young engineers were gladly recruited not only in the Baltics, but also in the Russian Empire. A. Baumanis went to West Russia - Beyaz, near Bryansk, which is now one of the districts of Bryansk, where he worked as a chemist. When World War I began, the engineer moved to Petrograd (today - St. Petersburg) and joined the Artillery Supply Factory. After the establishment of the Republic of Latvia, the Latvian engineer wanted to return to his home country and did it in 1919.

After returning to Latvia, A. Baumanis together with Jānis Kalniņš (1876-?) founded oil mill «J. Kalninga \& A. Baumaña ellas spiestuve» («J. Kalniņ̌ \& A. Baumais Oil Mill») which operated at 151 Brīvības iela 
in Riga until 31 December 1927. Jānis Pērkons (1854-1935), father-inlaw of $A$. Baumanis, performed the duties of warehouse manager of the mill\%[15]. Engineer A. Baumanis headed the company's Technical Department and was responsible for accounts, while J. Kalninš headed the Administrative Department [16]. The owners of the company J. Kalninšs and A. Baumanis, as well as J. Peerkons, lived next to the oil mill. Later, Augusts moved to work in his wife's property at 34a Dzirnavu iela, where the Technical Office of oil mill was located. The engineering company «J. \& A. Bauman» that carried out various engineering and construction works, such as sewerage and central heating installation, electrical installation, etc., was located at the mentioned address. The list of works carried out by the company included the construction of sewerage, gas and water pipes in the building of the Faculty of Agriculture of the University of Latvia at 1 Kronvalda bulvāris in Riga, where the Riga Technical University (until 1990 - RPI) had been operating since 1958. Larger works were carried out by this company also in Rēzekne, Kemeri, Talsi and Jelgava cities [17].

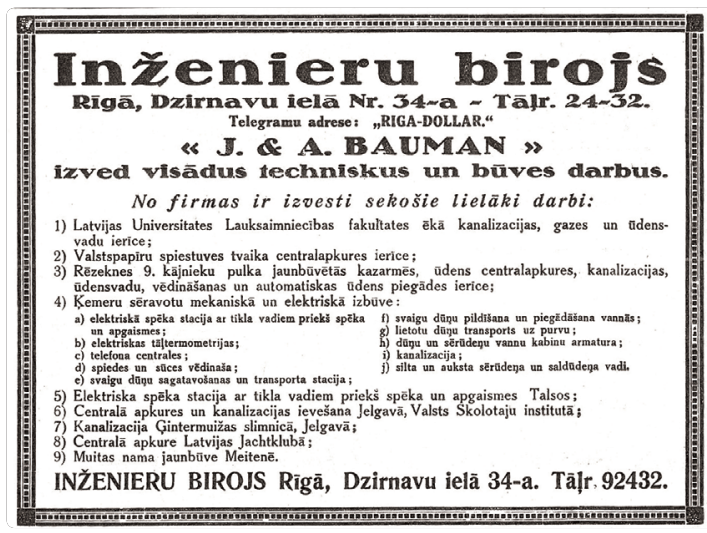

Figure 4. Advertisement of company «J. \& A. Bauman» (1925) [17].

In 1921, Augusts and his brother Jānis founded the company "Koku apstrādāšanas fabrika "Eksports»» («Wood Processing Factory «Eksports»"), which on 20 October 1921, operated at 24/2 Katrinas dambis in Riga [18] and was known not only there. The successful operation of the company was interrupted by a fire on 14 September 1926. It broke out in a wood sawmill, where stacked planks ignited from overheated steam pipes. The fire could only be extinguished after an hour when the roof of the building and the stacked planks had already burned down [19]. In January 1927, the brothers sold the company [20]. By the way, J. Kalniñš, former partner of A. Baumanis, was also engaged in timber industry - he had owned a sawmill in Riga since 1920. In the 
1930s, J. Kalniňš became the owner of the building at 34a Dzirnavu iela, which before that was owned by Irma Baumane [21].

On 2 August 1927, to the request of Augusts and Irma Baumani, at the register of matrimonial property, it was registered that the property of spouses had been separated [22]. The properties were mortgaged and during court proceedings the family had lost part of properties in Jürmala and Riga cities. On 12 April 1929, various items of I. Baumane were also auctioned - milk pasteurization boiler, dynamo engine and others [23].

At the end of 1924, Latvian Mutual Credit Union was established in order to deal with banking operations and to facilitate and support Latvian entrepreneurship [24]. Its founders were nine participants of corporation «Selonia», including A. Baumanis. The Credit Union was founded by former students and graduates of RPI: students of the Department of Commerce Kristjānis Bigge (1866-1941) and Jānis Eikerts (1883-1965); graduates of the same department Roberts Feldmanis (1881-1950) and Aleksandrs Evers (1880-1957); student of the Department of Agriculture Hugo Lapiñš (1867-1930); graduates of the Department of Engineering Fricis Stradiņš (1871-after 1944) and Andrejs Ķēze (also Kēese; 1881-1974); and graduate of the Department of Chemistry Gustavs Linde (1873-1934). Latvian Mutual Credit Union operated until 1940 when it was nationalized.

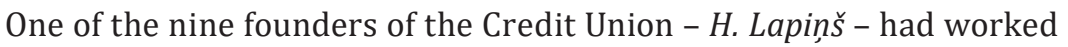
as Managing Director of gold mines in America. Perhaps his experience in a foreign country prompted another "polytechnician» to go abroad. In 1928, A. Baumanis travelled to the Republic of South Africa, which at that time was one of the leading gold mining and exporting countries. There he worked in gold mines. Unfortunately, author could not obtain information about his material gain there. It is known that the engineer returned to Latvia in 1931 [25].

\section{Engineer's Ideas on the Policy of National Economy}

After returning from the Republic of South Africa, the engineer prepared a report on «Economic Disadvantages of the Baltic States» and presented it at the Academic Section of the Latvian-Lithuanian Unit on 13 December 1931. The editorial board of newspaper «Jaunā Diena» («New Day»), which represented the interests of the Latvian Labour Union (1925-1934), recognized it as a very valuable material, pointing out that the issues and views discussed by the author corresponded to the party's ideology. A. Baumanis was a member of the Latvian Labour Union, actively participated in its work and made financial donations to 
it [26]. The article of the engineer-technologist A. Baumanis was published in the newspaper [27]. It contains author's suggestions regarding the economic and military issues, the negative sides of the existing economic facility and the advantages of the state economy. There are 10 theses in the article, which outline the need for countries to gradually take over the production, distribution and supply of foreign raw materials, to reduce the number of unemployed and involve them in state-important jobs such as use of peat, highway construction, waterway construction, drainage, etc., as well as to have artificial manure and superphosphate factory under state management to lower the production costs.

Being an engineer, A. Baumanis did not forget to include universities in his concept of national economy. In his opinion, it was necessary to establish special commissions of academics, agronomists, engineers, technicians, workers' organizations and consumers' associations, which would follow the information on technical progress, support rationalization, establish control and technical management, determine the type of organization of each branch of industry, company or factory and make decisions on gradual transition of industries to state control. It was recommended to establish a research institute under the auspices of the university to explore how to replace and produce raw materials and goods imported from abroad, to develop valid and cheap production methods and to implement them in industry. According to German experience, it should be considered how to replace gasoline completely and use lignite or peat in liquid fuel production for the countries with small economies such as the Baltic countries - Estonia, Latvia and Lithuania so that they would be less economically dependent on big countries.

The readers of the newspaper «Jaunā Diena» issue of 21 December 1931 were also able to learn about the engineer's proposals on the sale of agricultural products. A. Baumanis suggested that the municipalities take over the delivery of milk and meat products in the cities, to improve hygiene conditions, reduce the number of intermediaries and offer lower prices, as well as to modernize mechanization of production. In Baumanis' opinion, worthy of research was the possibility of exporting butter in cans, for example to Cuba, as well as collaboration with other agricultural countries. He recommended to involve in practical work agronomists, economists and engineers, hoping that under their leadership there would be serious work on economic issues for the sake of rapprochement of nations. The author of the thesis opposed external debts and concluded that «fierce competition requires from a private farm huge amounts of money, a lot of time and wasted energy in reciprocal combat, parallel production, search for market and loans, unnecessary advertising, overproduction, long storage of goods and redundant sellers and brokerage agents». 
To overcome the economic crisis, $A$. Baumanis offered other ideas, he was against armament, colonies and wars. After publishing his theses, newspaper «Jaunā Diena» in issues No. 1-6 of January and February 1932 published a wider outline. Other articles by A. Baumanis that were closely related to the economic prosperity of the countries and its problems, e.g. in France [28], were also published in the newspaper. On 17 April 1932, the 5th Congress of the Latvian Workers Union supplemented its program by including the recommendations of engineer $A$. Baumanis, which were considered necessary for farmers and workers, demanding for them higher and fixed wages as well as high and fixed prices for agriculture products [29].

A. Baumanis was interested in economics, economic growth and problems of countries. He became acquainted with the theory of an English economist as well as with economic theories of Manchester school [30]. His interest in economy was closely related to the ideology and goals of the Latvian Labour Union. The aim of the Union was to create a social state based on the principles and recommendations of Professor Kārlis Balodis (1864-1931) regarding national economy of Latvia, defending the poor and those of moderate wealth, fighting against those who only use the benefits of the Latvian nation. In early 1930s, the global economic crisis caused a lot of problems, unemployment increased and the country was in a difficult economic situation. The Latvian Labour Union stood in opposition to the government and was hoping to solve the problems by implementing the ideas and teachings of Professor K. Balodis [31]. Many of the valuable ideas that had been expressed and justified at the time were not realized.

\section{Pedagogical Work of $A$. Baumanis}

The knowledge in natural sciences and other subjects acquired at RPI was sufficient to teach in vocational schools, secondary schools, gymnasiums and elsewhere, thus almost every graduate of RPI worked as a teacher. After returning from the Republic of South Africa, A. Baumanis wanted to work in an educational institution. Although he did not have any pedagogical experience, he probably got interested about it during his conversations with his brother J. Baumanis, who had been working as a teacher in several vocational schools in Riga since 1927. The pedagogical work required a certificate of education and a permission had to be obtained to teach specific subjects. At the meeting on 22 February 1932, the Commission of Secondary and Vocational School Teachers of the Ministry of Education of the Republic of Latvia granted A. Baumanis 
a qualification of a secondary school teacher and the rights to teach chemistry, chemical technology and commerce [32]. Later, in 1934, the engineer wanted to obtain the right to teach other related subjects.

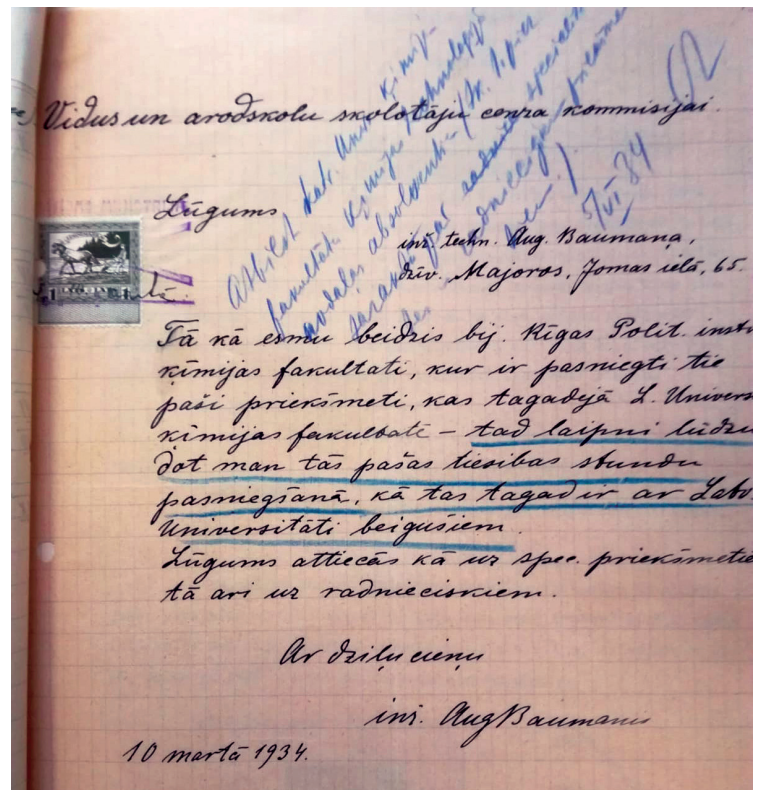

Figure 5. Request of $A$. Baumanis to the Commission of Secondary and Vocational School Teachers for the permission to teach more study subjects (10 March 1934) [33].

The pedagogical work of engineer-technologist A. Baumanis was related to Riga Teachers' Institute, where he started teaching chemistry in September 1932 [34]. The new workplace was in a rather convenient place for him - in Pārdaugava at Liepājas iela in Riga. When he commuted from Jürmala city to work, it was not necessary to go to the centre of Riga or even further. In addition, the train station was near the Institute. At that time, the director of the Institute was folklorist, poet, Lutheran pastor and teacher Ludis (Ludvigs Ernests) Bērzinšs (1870-1965). It was not known whether $A$. Baumanis (who was living in Jürmala) had been known L. Bērzinšs before he took the job at the Riga Teachers' Institute, but in 1934 the director moved to Jürmala city and the management of the Institute was entrusted to the science teacher - Jānis Bērziñš (18791952). Unfortunately, there is no evidence of the activities of A. Baumanis in the Institute [35]. His pedagogical work did not last long because since 1938, the Riga Teachers' Institute was moved to Césis city, where it operated as the Césis Teachers' Institute until 1940. A. Baumanis did not want to move to Cēsis city.

In 1938, A. Baumanis started working as a chemist in Riga - in the Department of Roads and Land Roads [36]. He still lived in Jūrmala city and remained there during World War II and post-war years. 


\section{Conclusions}

The first extensive study on engineer A. Baumanis reveals the problems that he had faced in business. Loans in banks and mortgages made it possible to raise funds and to set up and develop companies. For various reasons, including fire, economic crises and others, it has often been necessary to abandon and change employment. It happened also to A. Baumanis, who, after having worked in several companies, decided to focus on pedagogical work in educational institutions in Riga.

Like other Latvian engineers, A. Baumanis gained his first experience at the beginning of the 20th century in Russian enterprises far from his native country. The attempts to look for opportunities to «get out» abroad during the interwar period were not always successful. The global economic crisis and various local specific conditions did not contribute to the prosperity and long-term stay of Latvian engineers abroad. In the late 1920s and early 1930s, A. Baumanis became acquainted with the life and work of people in South Africa, but did not stay there for permanent living. In Latvia, the family was waiting for him and other challenges had to be met, there was also the loss of business. At the end of World War II, A. Baumanis took refuge and did not return to Latvia. However, besides losses and failures A. Baumanis also had bright and happy moments, opportunity to live in his homeland and to live in Jürmala city where his family had property until the 1960s.

\section{CONFLICT OF INTEREST}

The authors of the scientific article acknowledge a conflict of interest related to the joint professional work of the authors and members of the Editorial Board. The inclusion of this article in the issue was decided by those members of the Editorial Board who are not the authors of this article.

\section{LIST OF SOURCES AND LITERATURE}

[1] Trīnes Baumanes Latvijas Republikas pilsones pase. Latvijas Nacionālā arhīva Latvijas Valsts vēstures arhīvs (turpmāk - LNA LVVA) 2996. f., 2. apr., 9756. 1., 2.-8. lp.

[2] Rīgas Jēzus luteriskajā baznīcā 1883.un 1885. gadā kristīto saraksts. LNA LVVA 1407. f., 3. apr., 62. l., 435., 733. lp.

[3] Rīgas Jēzus luteriskās baznīcas mirušo registrs, 1885. gads. LNA LVVA 1407. f., 3. apr., 71. l., 38. lp. 
[4] Rīgas Politehniskā institūta studentu registrs. LNA LVVA 7175. f., 1. apr., 1906. l., 28. lp.

[5] Vīksna, A. Rainis un ārsti. Ārsts.lv, 2015. gada oktobris, 61. lpp.

[6] Trīnes Baumanes Latvijas Republikas pase, 1929. gads. LNA LVVA 2942. f., 1. apr., 9756. 1., 19. lp.

[7] Izraksti no Daugavgrīvas draudzes baznīcas grāmatas par 1921. gadu. LNA LVVA 1632. f., 1. apr., 1526. 1., 23., 24. lp.

[8] Mājas grāmata Turaidas ielā, Jūrmalā. LNA LVVA 2942. f., 1. apr., 13998. l., 10., 12. lp.

[9] Jānis Arnolds Baumanis. Austrālijas Latvietis, 2010. gada 20. janvāris, Nr. 2974, 11. lpp.

[10] An der Stadtrealschule. Duena Zeitung, 8 Juni 1904, Nr. 127, S. 5.

[11] RPI Arhitektūras nodaḷas studenta A. Baumaṇa lekciju grāmatinnas titullapa, 1904. gads. LNA LVVA 7175. f., 1. apr., 2142. l., 1. lp.

[12] RPI Ķimijas nodaḷas studenta A. Baumaṇa lekciju grāmatingas titullapa, 1904. gads. LNA LVVA 7175. f., 1. apr., 2131. l., 1. lp.

[13] Graudiņš, K. (sast.). Selonijas albums, 1880-1905. Jelgava: G. Landsbergs, 1905, 416. lpp.

[14] Latvijas Universitātes studenta Augusta Baumaṇa personāllieta. LNA LVVA 7427. f., 1. apr., 17914. l., 1.-6. lp.

[15] Jāṇa Kalniṇa un Jāṇa Pērkona apliecinājums par Augusta Baumaṇa darbu ellı las spiestuvē Rīgā 1932. gada 22. oktobrī. LNA LVVA 1632. f., 1. apr., 1526. l., 1. lp.

[16] J. Kalniṇa un A. Baumaṇa eḷlas spiestuves koplīguma kopija, 1922. gads. LNA LVVA 1632. f., 1. apr., 1526. l., 28. lp.

[17] Grīnšteins, R. Rokas grāmata importieriem un eksportieriem. Rīga: Autora izdevniecība, 1927, C9. lpp.

[18] RPI absolventa Riharda Miloševska liecība par brāḷu Baumaṇu firmu darbību, 1927. gads. LNA LVVA 1632. f., 1. apr., 1542. 1., 30. lp.

[19] Ugunsgrēks koku apstrādāšanas fabrikā. Rīgas Ziṇas apvienotas ar Latvijas Vēstnesi, 1926. gada 5. septembris, Nr. 207, 3. lpp.

[20] Notāra G. Zemgala pazinnojums Rīgas Biržas komitejai par J. un A. Baumaṇu firmas «Eksports» pārdošanu, 1927. gada janvārī. LNA LVVA 3143. f., 1. apr., 963. l., 196. lp.

[21] Mājas grāmata, Rīgā, Dzirnavu ielā 34 a, 20. gadsimta 30. un 40. gadi. LNA LVVA 2942. f., 1. apr., 4077. 1., 45. lp.

[22] Rīgas apr. I iec. miertiesnesis. Valdības Vēstnesis, 1937. gada 30. decembris, Nr. 296, 13. lpp.

[23] Rīgas pref. Jūrmalas. iec. pr-ks. Valdības Vēstnesis, 1929. gada 7. marts, Nr. 54, 4. lpp.

[24] Paziṇojums. Valdības Vēstnesis, 1924. gada 23. oktobris, Nr. 242, 4. lpp.

[25] Baumanis Augusts. Rīgas Politechnikums 1862.-1919. g.: Album academicum (1912.-1919. g.). Rīga: Latvijas universitātes studentu [padomes] grāmatnīca, 1938, 96. lpp.

[26] Latvijas darba savienības Rīgas nodaḷas sapulces dalībnieku saraksts, 1931. gada 17. decembrī. LNA LVVA 3260. f., 1. apr., 5. l., 15. lp.

[27] Baumanis, A. Jaunu virzienu saimnieciskā politikā! Jaunā Diena, 1931. gada 21. decembris, Nr. 0, 2.-3. lpp. 
[28] Baumanis, A. Francijas zelts un labklājība. Jaunā Diena, 1932. gada 21. aprīlis, Nr. 16, 2.-3. lpp.

[29] J. A. O. Latvijas Darba savienības V. kārtējais kongress. Dienas Lapa, 1932. gada 21. aprīlis, Nr. 16, 4. lpp.

[30] Baumanis, A. Jaunu virzienu saimnieciskā politikā! Jaunā Diena, 1932. gada 7. janvāris, Nr. 1, 2.lpp.

[31] Baumanis, J. Vai tas līdzēs? Jaunā Diena, 1931. gada 21. decembris, Nr. 0, 6. lpp.

[32] LR Izglītības ministrijas Vidusskolu direkcijas paziņojums A. Baumanim par viṇam piešksirto skolotāja cenzu, 1932. gada 26. februārī. LNA LVVA 1632. f., 1. apr., 1526. 1., 17., 19. lp.

[33] A. Baumaņa lūgums Vidus- un arodskolu skolotāju cenza komisijai aț̣aut mācīt vairāk mācību priekšmetus, 1934. gada 10. martā. LNA LVVA 1632. f., 1. apr., 1526. l., 19. lp.

[34] Rīgas pilsētas valdes lēmumi. Latvijas Kareivis, 1932. gada 14. septembris, Nr. 207, 4. lpp.

[35] Atmiṇu gaismā: Rīgas Skolotāju institūts (1922.-1938. g.) un Cēsu Valsts skolotāju institūts (1938.-1940. g.). Kalamazū: RSI un CVSI audzēkṇu puduris Kalamazū, 1990, 280. lpp.

[36] Baumanis Augusts. Rīgas Politechnikums 1862.-1919. g.: Album academicum (1912.-1919. g.). Rīga: Latvijas universitātes studentu [padomes] grāmatnīca, 1938, 96. lpp.

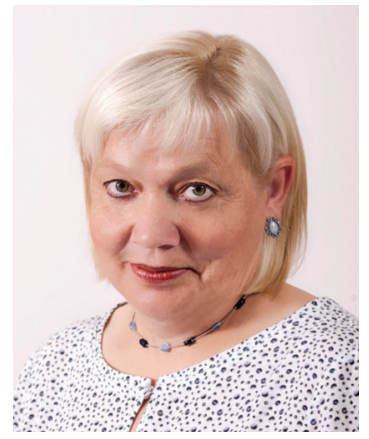

ALĪDA ZIGMUNDE, Dr. paed., has been a Specialist at the Museum of Riga Technical University since 1989. From 2007 to 2015, she was a Senior Researcher. She is currently a Professor with the Institute for Humanities and Head of the Department for Historic Research and Scientific Publications of the RTU Research Centre for Engineering History. Her main academic interests include the history of pedagogy in Europe, the history of the institutions of education and of private schools and the history of pedagogy of universities, history of engineering sciences and universities.

Address: 1 Kronvalda bulvāris, Room 203, Riga, LV-1010, Latvia

Phone: +37129869642

E-mail: alida.zigmunde@rtu.lv 


\section{Rīgas Politehniskā institūta absolventa Augusta Baumaṇa (1883- 1966) darbība inženierzinātnēs un pedagoǵijā}

Inženieris, uzṇēmējs un pedagogs Augusts Baumanis (1883-1966) pieder pie tiem Rīgas Politehniskā institūta (RPI) absolventiem, kuri bija pazīstami 20. gadsimta 20. un 30. gados un bez kuru darbības nav iedomājama Latvijas izaugsme. Pēc RPI Ķīmijas nodaḷas absolvēšanas (1913) viṇš strādāja Krievijā. 1919. gadā, atgriezies Latvijā, A. Baumanis iesaistījās ellıas ražošanā un koka dēlī̌su eksportēšanā. No 1928. līdz 1931. gadam viṇš kopā ar ǵimeni ceḷoja pa Dienvidāfriku un strādāja zelta raktuvēs. Atgriezies Latvijā, A. Baumanis strādāja par skolotāju. Raksta mērķis ir atklāt inženiera A. Baumaṇa dzīvesdarbību, iepazīstināt lasītājus ar latviešu uzṇēmēju un izanalizēt problēmas, ar kurām viṇam bija jāsastopas uzṇēmējdarbībā un pedagoǵijā starpkaru laikā.

Atslēgas vārdi: Augusts Baumanis, Rīgas Politehniskais institūts, Rīgas inženieri un skolotāji.

\section{Алида Зигмунде}

\section{Деятельность выпускника Рижского политехнического института Августса Бауманиса (1883-1966) в области инженерных наук и педагогики}

Инженер, предприниматель и педагог Августс Бауманис (1883-1966) принадлежит к тем выпускникам Рижского политехнического института (РПИ), которые были известны в 20-30-ых годах XX века и без чьей деятельности развитие Латвии было бы немыслимо. После окончания Химического отделения РПИ (1913) он работал в России. После возвращения в Латвию в 1919 году А. Бауманис стал заниматься производством масла и экспортом деревянных досок. С 1928 по 1931 год он со своей семьей путешествовал по Южной Африке и работал на золотых приисках. Вернувшись в Латвию, А. Бауманис работал учителем. Цель статьи - осветить жизненную деятельность инженера А. Бауманиса, познакомить читателей с латвийским предпринимателем и проанализировать проблемы, с которыми ему пришлось столкнуться в бизнесе и педагогике в межвоенный период.

Ключевые слова: Августс Бауманис, Рижский политехнический институт, инженеры и учителя Риги. 